\title{
Kreativitas Siswa dalam Mata Pelajaran IPA
}

\author{
Hasrani Siregar ${ }^{1}$ \\ ${ }^{1}$ Sekolah Menengah Pertama 6 Batanghari, Jambi, Indonesia
}

\begin{tabular}{l}
\hline \hline Article Info \\
\hline Article history: \\
Received Des 21, 2019 \\
Revised Des 27, 2019 \\
Accepted Jan 1, 2020 \\
\hline
\end{tabular}

\section{Keywords:}

IPA

Kretivitas

SMP

\begin{abstract}
ABSTRAK
Tujuan Penelitian: Penelitian ini bertujuan untuk mengetahui kreativitas belajar siswa terhadap matapelajaran IPA di SMPN 6 Batanghari.

Metodologi: Penelitian ini mengunakan metode kuantitatif menggunakan instrumen angket. Sampel yang digunakan dalam penelitian ini sebanyak 143 siswa di SMPN 6 Batanghari. Tekhnik analisis data yang digunakan adalah statistik deskriptive.
\end{abstract}

Temuan utama: Hasil yang diperoleh dari penelitian ini yaitu pada indikator memberi gagasan atau usulan terhadap suatu masalah,menanggapi pendapat teman,mengajukan pertanyaan, dan membuat/mencari tahu sendiri dalam matapelajaran IPA di SMPN 6 Batanghari tergolong berkategori baik

Keterbaruan penelitian: Keterbaharuan dari penelitian ini ialah belum adanya penelitian yang mengkaji suatu permasalahan pendidikan berdasarkan aspek kretivitas siswa di SMP 6 Batanghari.

This is an open access article under the $\mathrm{CCBY-NC}$ license

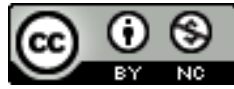

\section{Corresponding Author:}

Hasrani Siregar, SMPN 6 Batanghari, Jambi, Indonesia

Jln. Sei. Abang Km.5 Muara Tembesi, Kampung Baru, Kec. Muara Tembesi, Kab. Batang Hari Email: siregarhasrani@gmail.com

\section{PENDAHULUAN}

Indonesia sebagai Negara berkembang dalam menghadapi kemajuan globalisasi dibutuhkan generasi penerus bangsa yang lebih produktif dan kompetitif. Untuk itu perlu adanya pembangunan dalam berbagai bidang. Salah satunya pada bidang pendidikan. Education is a processing effort carried out by someone to gain knowledge, skills, and habits in life [1]. Education is basically a conscious effort to grow and develop the potential of human resources, especially students, which is carried out by guiding and facilitating their learning activities [2]. Pendidikan adalah suatu kegiatan, yang sangat penting bagi semua manusia, dengan adanya pendidikan manusia dapat merubah tingkah laku dan pengetahuan menjadi lebih baik [3]. Sehingga pendidikan dimaknai sebagai usaha membantu peserta didik dalam mengembangkan potensinya untuk menghadapi masa depan [4]. Salah satu lembaga pendidikan yang membantu peserta didik dalam mengembangkan potensi dirinya adalah sekolah [5]. Disekolah peserta didik mengikuti proses pembelajaran yang bertujuan untuk mencapai tujuan pendidikan. Didalam proses pembeajaran peserta didik berperan aktif, siswa diharapkan dapat lebih berperan aktif selama kegiatan pembelajaran. Pembelajaran harus sebanyak mungkin melibatkan peserta didik [6]. Selain itu, peran guru sangat di butuhkan dalam menciptkan pembelajaran aktif. Guru harus memiliki kompetensi pedagogik, yaitu kemampuan yang berkaitan dengan pengelolaan pembelajaran yang mendidik [7].

Proses pembelajaran dapat membantu siswa dalam berinteraksi dan membentuk karakter. Character education in order to help students not only to become smart but also to become good [8]. Didalam 
pembentukan karakter ini guru merupakan kunci utama yang membantu pembentukan karakter pada diri siswa melalui proses pembelajaran. The success of the learning process is influenced by the quality and way of teaching a teacher [9]. Proses pembelajaran yang diberikan oleh guru kepada siswa bertujuan untuk membantu tercapainnya tujuan pendidikan dan pemahaman yang lebih mendalam pada suatu konsep sehingga dapat memberikan hasil belajar yang optimal. Kemampuan guru dalam mengelola siswa termasuk pemahaman siswa, mengembangkan kurikulum/silabus, merancang pembelajaran dan mengaktualisasikan berbagai potensi siswa sangat di perlukan [10].

Salah satu matapelajaran disekolah yang membutuhkan pemahaman konsep yang lebih mendalam untuk mendapatkan hasil yang lebih optimal adalah matapelajaran IPA. Natural Science is the learning process which is highly related to the environment and the regularity of the universe created by God the almighty [11]. IPA erat kaitannya dengan alam sehingga menjadikan matapelajaran IPA menjadi matapelajaran yang terbilang sulit bagi siswa karena bersifat abstrak. Untuk itu dalam memahami matapelajaran IPA dibutuhkan suatu sikap positif dari dalam diri siswa. A positive attitude is indicated by students tend to be more diligent in learning so that they get satisfying results, whereas a negative attitude is characterized by students being less diligent in learning so that they get unsatisfactory results [12-14]. Sikap terhadap IPA adalah suatu bentuk keteraturan berperilaku terhadap pembelajaran IPA yang teruji kebenarannya secara objektif. Sikap IPA merupakan faktor utama yang mempengaruhi peserta didik dalam mencapai hasil belajar yang optimal pada matapelajaran IPA [15]. Kepercayaan siswa terhadap suatu mata pelajaran juga mempengaruhi sikap siswa terhadap mata pelajaran tersebut [16]. Sikap yang dapat di kembangkan dalam proses pembelajaran IPA ialah sikap ilmiah. Scientific attitude is an attitude that must be possessed by students in learning science such as honesty, curiosity, responsibility, thoroughness, discipline, etc., while attitudes toward science are merely attitudes about the likes or dislikes that students have or feel towards science learning [17]. Namun selain menanamkan sikap positif pada diri peserta didik diperlukannya juga penanaman nilai karakter kreativitas belajar siswa,karena kreativitas belajar menjadi faktor penting yang dapat membantu siswa dalam memahami konsep-konsep pada matapelajaran IPA.

Kreativitas menurut [18], creativity involyes a set of atributes (like self confidence desire for achievement,sensitivity) and thinking skills (like fluency,mental flexibility,imagination). Karena itulah kreativitas belajar sangat dibutuhkan untu menunjang siswa dalam memahani konsep-konsep IPA.

Oleh karenanya dengan mengetahui tingkat kreativitas belajar siswa dapat membantu guru dalam proses pembelajaran IPA dan memberikan bekal pengetahuan bagaimana cara mengidentifikasi kreativitas belajar siswa terkait matapelajaran IPA, dan memberikan dampak positif bagi siswa sehingga dapat meningkatkan pemahaman siswa terhadap matapelajaran IPA. Tujuan dari penelitian ini adalah untuk mengetahui kreativitas belajar siswa terhadap IPA di SMPN 6 BATANGHARI. Dalam penelitian ini pertanyaan yang ditunjukan adalah 1) Bagaimana kreativitas belajar siswa ditinjau dari indikator memberi Gagasan atau Usulan terhadap suatu masalah 2) Bagaimana Kreativitas belajar siswa ditinjau dari indikator Menanggapi pendapat teman 3) Bagaimana Kreativitas belajar siswa ditinjau dari indikator Mengajukan pertanyaan 4) Bagaimana Kreativitas belajar siswa ditinjau dari indikator Membuat/mencari soal sendiri untuk dipecahkan. Sehingga berdasarkan hasil observasi yang dilakukan di SMPN 6 Batanghari peneliti ingin mengetahui kreativitas belajar siswa terhadap matapelajaran IPA guna membantu guru dan memberikan dampak positif dalam proses pembelajaran IPA.

\section{METODE PENELITIAN}

Berdasarkan permasalah yang ditinjau dari tujuan penelitian rancangan penelitian yang digunakan oleh peneliti adalah survei dengan menggunakan metode kuantitatif. Menurut [19] penelitian survei biasanya menggunakan metode pengamatan, Pengamatan dapat dilakukan dengan cara wawancara atau dengan membagikan kuisioner. Metode kuantitatif dipilih karena sesuai dengan rancangan penelitian yaitu untuk meneliti populasi atau sampel tertentu guna mnguji hipotesis. Dengan menggunakan metode kuantitatif dapat membantu peneliti mendeskripsikan kreativitas belajar siswa terhadap matapelajaran IPA.

Teknik pengambilan sampel yang digunakan ialah purposive sampling dengan jumlah subjek sebanyak 143 siswa di SMPN 6 Batanghari. Purposive sampling adalah teknik pengambilan sampel berdasarkan kriteria dari peneliti [20]. Teknik ini digunakan untuk melihat deskripsi kreativitas belajar siswa terhadap matapelajaran IPA di SMPN 6 BATANGHARI pada matapelajaran IPA.

Instrumen penelitian yang digunakan oleh peneliti adalah angket kreativitas belajar yang merupakan angket tertutup. The respondent must choose from a set of given answers. These tend to be quick to answer, easy to code and require no special writing skills from the respondent. However, they do limit the range of possible answers [21] Skala yang digunakan adaah skala linkert lima poin yang terdiri dari STS=sangat tidak setuju, TS=tidak setuju, $\mathrm{N}=$ netral, $\mathrm{S}=$ setuju, $\mathrm{SS}=$ sangat setuju Angket Kreativitas di adopsi dari penelitian [18] dengan Cronbach alpha sebesar 0,977, penelitian [22] dan [24] dengan cronbach alpha sebesar 0,753.

JEE. Vol. 1, No. 1, Januari 2020: 21 - 26 
Prosedur yang dilakukan pada penelitian ini adalah dengan menyebaran kuisioner lalu melakukan analisis data kreativitas belajar siswa kemudian dilanjutkan dengan mentranskip seluruh data yang diperoleh selama penelitian berlangsung kedalam tabel hasil.

Analisis data yang digunakan dalam penelitian ini adalah analisis deskriptif. Data yang disajikan dalam jumlah besar yang mencakup mean, modus, median, maksimum, minimum, dan standar deviasi merupakan statistik deskriptif [25] Data di olah menggunakan aplikasi SPSS 22 dengan tujuan mendapatkan nilai presentase,Frekuensi,rata-rata dan standar deviasi.

\section{HASIL DAN PEMBAHASAN}

\subsection{Memberi Gagasan atau Usulan terhadap suatu masalah}

Berdasarkan data yang dianalisis menggunakan statistik deskriptif diperoleh hasil untuk indikator memberi gagasan atau usulan terhadap suatu masalah sebagai berikut:

Tabel 1 Indikator Memberi Gagasan atau Usulan terhadap suatu masalah siswa di SMPN 6 Batanghari

\begin{tabular}{cccccc}
\hline Rentang & Kategori & Jumlah & $\%$ & Min & Max \\
\hline $6,0-10,8$ & Sangat Tidak Baik & 1 & 0,7 & & \\
$10,9-15,6$ & Tidak Baik & 4 & 2,8 & & \\
$15,7-20,4$ & Netral & 42 & 29,4 & 8 & 39 \\
$20,5-25,2$ & Baik & 81 & 56,6 & & \\
$25,3-30,0$ & Sangat Baik & 15 & 10,5 & & \\
\hline & Total & 143 & 100,0 & & \\
\hline
\end{tabular}

Dari tabel 1 dapat diketahui tingkat kreativitas belajar siswa pada indikator memberi gagasan atau usulan terhadap suatu masalah dalam matapelajaran IPA di SMPN 6 Batanghari dapat dilihat dari respon siswa berkategori Sangat Tidak Baik sebanyak 0,7\%(1 dari 143 siswa) kemudian untuk kategori Tidak Baik sebanyak 2,8\%(4 dari 143 siswa) lalu untuk kategori Netral sebanyak 29,4\%(42 dari 143 siswa) sedangkan untuk kategori Baik sebanyak 56,6\%(81 dari 143 siswa) dan untuk kategori Sangat Baik sebanyak 10,5\% (15 dari 143 siswa). Dengan skor minimal pada seluruh pernyataan sebesar 8,00 dan skor maksimal sebesar 39,00. Berdasarkan hasil analisis data yang diperoleh menunjukan bahwa Sikap siswa pada indikator memberi gagasan atau usulan terhadap suatu masalah IPA di SMPN 6 Batanghari dominan berkategori baik.

Dari hasil penjabaran pada tabel 1 menunjukan kreativitas belajar siswa pada indikator memberi gagasan atau usulan terhadap suatu masalah dalam mataplajaran IPA di SMPN 6 Batanghari berkategori baik. Artinyaa siswa mampu mengungkapkan gagasan atau ide yang dimilikinya dalam menanggapi suatu persoalan. Kreativitas adalah kemampuan untuk mengasilkan gagasan baru, memecahkan masalah, ide [26].

\subsection{Menanggapi pendapat teman}

Berdasarkan data yang dianalisis menggunakan statistik deskriptif diperoleh hasil untuk indikator menanggapi pendapat teman sebagai berikut:

Tabel 2 Indikator Menanggapi pendapat teman siswa di SMPN 6 Batanghari

\begin{tabular}{cccccc}
\hline Rentang & Kategori & Jumlah & $\%$ & Min & Max \\
\hline $2,0-3,6$ & Sangat Tidak Baik & 1 & 7 & & \\
$3,7-5,2$ & Tidak Baik & 31 & 21,7 & & \\
$5,3-6,8$ & Netral & 37 & 25,9 & 3 & 10 \\
$6,9-8,4$ & Baik & 55 & 38,5 & & \\
$8,5-10,0$ & Sangat Baik & 19 & 13,3 & & \\
\hline \multicolumn{7}{c}{ Total } & 143 & 100,00 & \\
\hline
\end{tabular}

Dari tabel 2 dapat diketahui tingkat kreativitas belajar siswa pada indikator menanggapi pendapat teman dalam matapelajaran IPA di SMPN 6 Batanghari dapat dilihat dari respon siswa berkategori Sangat Tidak Baik sebanyak 7\%(1 dari 143 siswa) kemudian untuk kategori Tidak Baik sebanyak 21,7\%(31 dari 143 siswa) lalu untuk kategori Netral sebanyak 25,9\%(37 dari 143 siswa) sedangkan untuk kategori Baik sebanyak 38,5\%(55 dari 143 siswa) dan untuk kategori Sangat Baik sebanyak 13,3\% (19 dari 143 siswa). Dengan skor minimal pada seluruh pernyataan sebesar 3,00 dan skor maksimal sebesar 10,00. Berdasarkan hasil analisis data yang diperoleh menunjukan bahwa Sikap siswa pada indikator menanggapi pendapat teman IPA di SMPN 6 Batanghari dominan berkategori Baik. 
Dari hasil penjabaran pada tabel 2 menunjukan kreativitas belajar siswa pada indikator menanggapi pendapat teman dalam mataplajaran IPA di SMPN 6 Batanghari berkategori baik. Artinya siswa berusaha memberikan pendapat yang berbeda dari temannya sehingga dapat memberikan wawasan pengetahuan yang lebih dalam memperdalam konsep IPA.

\subsection{Mengajukan pertanyaan}

Berdasarkan data yang dianalisis menggunakan statistik deskriptif diperoleh hasil untuk indikator mengajukan peranyaan sebagai berikut:

Tabel 3 Indikator Mengajukan pertanyaan siswa di SMPN 6 Batanghari

\begin{tabular}{cccccc}
\hline Rentang & Kategori & Jumlah & $\%$ & Min & Max \\
\hline $3,0-5,4$ & Sangat Tidak Baik & 0 & 0 & & \\
$5,5-7,8$ & Tidak Baik & 3 & 2,1 & & \\
$7,9-10,2$ & Netral & 39 & 27,3 & 7 & 15 \\
$10,3-12,6$ & Baik & 51 & 35,7 & & \\
$12,7-15,0$ & Sangat Baik & 50 & 35,0 & & \\
\hline Total & 143 & 100 & \\
\hline
\end{tabular}

Dari tabel 3 dapat diketahui tingkat kreativitas belajar siswa pada indikator mengajukan pertanyaan dalam matapelajaran IPA di SMPN 6 Batanghari dapat dilihat dari respon siswa berkategori Sangat Tidak Baik sebanyak 0\%(0 dari 143 siswa) kemudian untuk kategori Tidak Baik sebanyak 2,1\%(3 dari 143 siswa) lalu untuk kategori Netral sebanyak 27,3\%(39 dari 143 siswa) sedangkan untuk kategori Baik sebanyak 35,7\% (51 dari 143 siswa) dan untuk kategori Sangat Baik sebanyak 35,0\% (50 dari 143 siswa). Dengan skor minimal pada seluruh pernyataan sebesar 7,00 dan skor maksimal sebesar 15,00. Berdasarkan hasil analisis data yang diperoleh menunjukan bahwa Sikap siswa pada indikator mengajukan pertanyaan IPA di SMPN 6 Batanghari dominan berkategori Baik. Hasil pengolahan data pada indikator Membuat/mencari soal sendiri untuk dipecahkan.

Dari hasil penjabaran pada tabel 3 menunjukan kreativitas belajar siswa pada indikator mengajukan pertanyaan dalam mataplajaran IPA di SMPN 6 Batanghari berkategori baik. Artinya ketika menemukan sesuatu yang berbeda dari yang diketahui siswa memiliki keberanian dalam mengajukan pertanyaan agar dapat menambah serta memberikan pengetahuan yang lebih terhadap suatu permasalahan dalam matapelajaran IPA.

\subsection{Membuat/mencari soal sendiri untuk dipecahkan}

Berdasarkan data yang dianalisis menggunakan statistik deskriptif diperoleh hasil untuk indikator membuat/mencari soal sendiri untuk dipecahkan sebagai berikut:

Tabel 4 Indikator Membuat/mencari soal sendiri untuk dipecahkan siswa di SMPN 6 Batanghari

\begin{tabular}{cccccc}
\hline Rentang & Kategori & Jumlah & $\%$ & Min & Max \\
\hline $6,0-10,8$ & Sangat Tidak Baik & 9 & 6,3 & & \\
$10,9-15,6$ & Tidak Baik & 31 & 21,7 & & \\
$15,7-20,4$ & Netral & 43 & 30,1 & 2 & 8 \\
$20,5-25,2$ & Baik & 44 & 30,8 & & \\
$25,3-30,0$ & Sangat Baik & 16 & 11,2 & & \\
\hline \multicolumn{7}{c}{ Total } & 143 & 100,0 & \\
\hline
\end{tabular}

Dari tabel 4 dapat diketahui tingkat kreativitas belajar siswa pada indikator membuat atau mecari soal sendiri untuk dipecahkan dalam matapelajaran IPA di SMPN 6 Batanghari dapat dilihat dari respon siswa berkategori Sangat Tidak Baik sebanyak 6,3\%(9 dari 143 siswa) kemudian untuk kategori Tidak Baik sebanyak 21,7\%(31 dari 143 siswa) lalu untuk kategori Netral sebanyak 30,1\%(43 dari 143 siswa) sedangkan untuk kategori Baik sebanyak 30,8\%(44 dari 143 siswa) dan untuk kategori Sangat Baik sebanyak 11,2\% (16 dari 143 siswa). Dengan skor minimal pada seluruh pernyataan sebesar 2,00 dan skor maksimal sebesar 10,00. Berdasarkan hasil analisis data yang diperoleh menunjukan bahwa Sikap siswa pada indikator membuat atau mecari soal sendiri untuk dipecahkan IPA di SMPN 6 Batanghari dominan berkategori Baik.

Diketahui dari hasil yang diperoleh dari masing-masing indikator menunjukan deskripsi kreativitas belajar siswa di SMPN 6 Batanghari tergolong Baik. Hal ini menunjukan bahwa siswa di SMPN 6 Batanghari memiliki tingkat kreativitas belajar yang baik dalam matapelajaran IPA bila ditinjau dari ke empat indikator sehingga bila dihadapan pada suatu persoalan IPA siswa memiliki rasa ingin tahu dan dapat 
menyelesaikan persoalan tersebut dengan baik,sehingga dapat meningkatkan hasil belajar yang diperoleh pada matapelajaran IPA. The role of teachers in varying learning model becomes a factor that allows stuents to use all thei potential, to find their own concept plus other mental processes that provide adult or characteristics of the humanist, so students can find self-concept, critical and creative concepts [27].

\section{KESIMPULAN}

Berdasarkan hasil penelitian yang telah dilakukan menunjukan kreativitas belajar siswa pada indikator memberi gagasan atau usulan terhadap suatu masalah, menanggapi pendapat teman,mengajukan pertanyaan, dan membuat/mencari tahu sendiri dalam matapelajaran IPA di SMPN 6 Batanghari tergolong berkategori baik. Siswa memiliki tingkat kreativitas belajar yang baik terhadap matapelajaran IPA

\section{UCAPAN TERIMA KASIH}

Peneliti mengucapkan terima kasih kepada kepala sekolah dan siswa-siswi SMPN 6 Batanghari yang telah membantu dalam mensukseskan penelitian ini.

\section{REFERENSI}

[1] Asril, Syahrial, D.A. Kurniawan, F. Chan, R. Septianingsih, and R. Perdana, "Multimedia Innovation 4.0 in Education: E-Modul Ethnoconstructivism," Universal Journal of Education Research, vol. 7, no. 10, pp 2098-2107, 2019

[2] Astalini, D. A. Kurniawan, \& Sumaryanti. "Sikap Siswa Terhadap Pelajaran Fisika Di SMAN Kabupaten Batanghari," Jurnal ilmu pendidikan fisika, vol. 3, no. 2, pp. 59-64, 2018

[3] Astalini et all. "Identifikasi Sikap Peserta Didik terhadap Mata Pelajaran Fisika di Sekolah Menengah Atas Negeri 5 Kota Jambi," Unnes Physics Education Journal. Vol. 8, No. 1, 2019

[4] P. Asriani, S. Cholis, A. Sa'dun, "Bahan Ajar Berbasis Pendidikan Karakter Untuk Siswa Kelas Iv Sekolah Dasar," Jurnal Pendidikan, vol. 2, no. 11, pp. 1456-1468. 2017

[5] B. Timutiasari, M.H.I. Al-Muhdhar, and Suhadi, "Pembelajaran Berbasis Proyek Berbantuan Modul Program Krpl Untuk Mengembangkan Sikap Peduli Lingkungan Dan Keterampilan Proses Sains Siswa Sd Islam Moh. Hatta Malang," Jurnal Pendidikan, vol. 1, no. 6, pp. 1185-1190

[6] I. M. T. Murningsih, M. Masykuri, and B. Mulyani, "Penerapan Model Pembelajaran Inkuiri Terbimbing untuk Meningkatkan Sikap Ilmiah dan Prestasi Belajar Kimia Siswa," Jurnal Inovasi Pendidikan IPA, vol. 2, no. 2, pp. 177-189. 2016.

[7] Asrial, Syahrial, D.A. Kurniawan, and N. Amalina, "Analisis Hubungan Kompetensi Bahasa Indonesia terhadap Kompetensi Pedagogik Mahasiswa Pendidikan Guru Sekolah Dasar,” Jurnal Pendidikan Dasar dan Pembelajaran., vol. 9, no. 1, pp. 1-8, 2019.

[8] M. A. Putri, and S. Harto, "Promoting Character Education in Efl Classroom:Using Children'S Literature As a Teaching Material, vol. 5, no. 2, pp. 163-169. 2017.

[9] D. Darmaji, D.A. Kurniawan, and A. Suryani, "Effectiveness of Basic Physics II Practicum Guidelines Based On Science Process Skills. JIPF (Jurnal Ilmu Pendidikan Fisika), vol. 4, no. 1, pp. 1-7. 2019.

[10] Syahrial, Asrial, D.A. Kurniawan, and M. Subandiyo," Pedagogic Competence and Indonesian Language Competence Pre-Service Teacher of Elementary Program," International Journal of Scientific \& Technology Research, vol. 8, no. 10, pp 851-856. 2019.

[11] A. Susilawati, H. Hernani, and P. Sinaga, "The Application of Project-Based Learning Using Mind Maps To Improve Students' Environmental Attitudes Towards Waste Management in Junior High Schools," International Journal of Education, vol. 9, no. 2, pp. 120. https://doi.org/10.17509/ije.v9i2.5466. 2017.

[12] Maison, Astalini, D. A. Kurniawan, \& L. R. Sholihah. "Deskripsi Sikap Siswa SMA Negeri pada Mata Pelajaran Fisika," EDUSAINS. Vol. 10, no. 1, PP. 160-167, 2018

[13] Astalini, D. A. Kurniawan, R. Perdana, \& D. Kurniasari. "Identification of Student Attitudes toward Physics Learning at Batanghari District High School,” The Educational Review, USA, vol. 2, no. 9, pp. 475-484, 2018 https://doi.org/10.26855/er.2018.09.003

[14] Astalini, D. A. Kurniawan, A. D. Putri, and R. Nawangsih. "Identifiy student's attitude towards the subject of natural science,” vol. 13, no. 3, pp. 386-394, 2019 https://doi.org/10.11591/edulearn.v13i3.13144.

[15] Astalini, A., Kurniawan, D.A., Melsayanti, R., \& Destiati,A, "Sikap Terhadap Mata Pelajaran Ipa Di Smp SeKabupaten Muaro Jambi,” Jurnal Litera Pendidikan, vol. 21, no. 2, pp. 214-227. 2018.

[16] Maison, Syahrial, Syamsurizal, and Tanti, “ Learning Environment, Students' Beliefs, and Self-Regulation in Learning Physics: Structural Equation Modeling,” Journal of Baltic Science Education, vol. 18, no. 3, pp 389-403, 2019 . 
[17] D. A. Kurniawan, A. Astalini, Susanti, and Maison, "Attitudes of College Students on the Subject of Mathematical Physics III in Physics Education Program of Jambi University,” The Educational Review, USA, Vol. 2, No. 11, pp. 505-513, 2017 http://dx.doi.org/10.26855/er.2018.11.001.

[18] Z. Fieldz, and C. Bisschoff, "Developing and Assessing a Tool to measure The Creativity of University Student. $J$ Soc Sci, vol. 38, no. 1, pp. 23-31. 2018

[19] V.H. Kristanto,’Metodelogi Penelitian Pedoman Penulisan Karya Tulis Ilmiah (KTI),” Yogyakarta:Deepublish. 2018.

[20] Kerlinger, F. N. Foundations of behavioural research. Yogyakarta: Gadjah Mada University Press. 2014

[21] Walliman, Nicholas. Research Methods The Basics. Routledge: New York. 2011

[22] Cohen, L., Manion, L., \& Marrison, K. Research Methods in Education, New York. Routledge. 2007

[23] Farida, N. Pengaruh Sikap Kreatif Terhadap Prestasi Belajar Matematika. Jurnal Pendidikan Matematika, 2(2), 1015. 2014

[24] Zahra, L., Kusmayadi, T. A., \& Usodo, B.. Studi Deskriptif Keterampilan Bertanya Gurupada Proses Pembelajaran Matematika Ditinjau Dari Pengalaman Mengajar Di Sma Taman Madya Probolinggo Tahun Pelajaran 2016/2017. Jurnal Pendidikan Mateatika,1(2) 156-166. 2016

[25] Rosnia, D., \& Junita, H. Peningkatan Kemampuan Pemecahan Masalah Siswa Sd Dalam Pembelajaran Matematika Dengan Model Diskursus Multy Representation (Dmr). Jurnal Pendidikan Dasar, 9(1), 35-46. 2017

[26] Aini,dkk. Montase Dan Pembelajaran (Montase Sebagai Pembangun Daya Fikir Dan Kreativitas Anak Usia Dini). Ponorogo : Uwais Inspirasi Indonesia.

[27] Syahrial, et al, “Increased Behavior of Students' Attitudes to Cultural Values Using the Inquiry Learning Model Assisted Ethno Constructivism,” Journal of Educational Science and Technology, vol. 5, no. 2, pp 166-175, 2019.

JEE. Vol. 1, No. 1, Januari 2020: 21 - 26 